\title{
Effect of Tannin Content in Horse Bean on Rumen Fermentation in vitro
}

\author{
Wojciech Zawadzki ${ }^{1}$, Albert Czerski ${ }^{1}$, Edyta Wincewicz $^{1}$, Jan Gnus ${ }^{2}$, \\ Agnieszka Balcerzak ${ }^{1}$, Andrzej Kotecki ${ }^{3}$, Marcin Kozak ${ }^{3}$ \\ ${ }^{1}$ Department of Animal Physiology, Wroclaw University of Environmental and Life Sciences, Wrocław, Poland \\ ${ }^{2}$ General and Vascular Surgery Ward, Provincial Specialized Hospital, Research and Development \\ Center in Wrocław, Poland \\ ${ }^{3}$ Department of Crop Productions, Wroclaw University of Environmental and Life Sciences, Wrocław, Poland
}

Received November 18, 2008

Accepted October 21, 2009

\begin{abstract}
The objective of the experiments was to demonstrate the influence of low- and high-tannin horse bean on the selected fermentation indicators. The sheep rumen content with the addition of 1,2 and $5 \mathrm{~g}$ of high- and low-tannin horse bean was incubated in vessels of $250 \mathrm{ml}$ volume. A significant increase of ammonia, lactic acid, $\mathrm{CO}_{2}$ and methane as well as $\mathrm{pH}$ decrease in samples with addition of horse bean seed was demonstrated. While comparing high- and low-tannin horse bean varieties, it was observed that in the case of small doses of 1 and $2 \mathrm{~g}$ a higher intensity of fermentation takes place in the samples with the addition of high-tannin horse bean. In the case of larger doses of $5 \mathrm{~g}$ per sample, a higher intensity of fermentation takes place in the samples with the addition of low-tannin horse-bean. A probable reason for the decrease in the fermentation process intensity in the samples with the addition of $5 \mathrm{~g}$ of high-tannin horse bean is a high content of tannins, which reduce fermentation processes.
\end{abstract}

Sheep, fermentation, rumen, horse bean, in vitro

A ban on the inclusion of meat-bone meal in the ruminant feeding has resulted in a greater interest of breeders in high-protein plant fodders. These fodders are considerably cheaper than the meat-bone meal and do not involve a risk of infectious diseases. One disadvantage of the fodders is worse protein balance in the amino-acid composition. Horse bean belongs to this type of fodders. Its high nutritive value is associated with a high protein content of high biological value. The horse bean seeds contain approximately $26-30 \%$ of the total protein. Globulins are the main protein, which constitutes $55 \%$ to $70 \%$ of the total protein (Jasińska and Kotecki 1998a; 2003). A disadvantage of the protein contained in the horse bean is the low content of some amino acids, i.e. methionine, cysteine, tryptophan and threonine, whereas its content of lysine is high (Jasińska and Kotecki 1993). The fat content in the horse bean seeds is very low. The horse bean also contains a substantial amount of sugar, including a lot of starch and hemicellulose amounting to approximately $58 \%$. It is also rich in minerals and vitamins (Jasińska and Kotecki 2003; Pavlata et al. 2002). There are certain compounds in the horse bean that limit the bioavailability of nutritive components and disturb the functions of glands and internal organs through which they worsen health and reduce animal productivity. The following compounds belong to the above-mentioned ones: tannins, protease inhibitors, lectins, glycosides, phytates, alphaamylase and oligosaccharide inhibitors (Jasińska and Kotecki 1998b).

Tannins are intermediate metabolites of the plant synthesis. They are structurally divided into two groups: proanthocyanidins (the condensed tannins) and polyesters of the gallic acid and the hexahydroxydiphenic acid (Hasam 1981). Tannins have the task of protecting the plants against herbivorous animals and those microorganisms that are pathogenic to plants (fungi, bacteria) (Provenza 1995; Scalbert 1991; Hart and Hillis 1972). Tannins have an impact on decreasing the animal's appetite, which already appears 20-60 min after administration of the horse bean fodder (a short-term effect). The addition of the horse

Address for correspondence:

Wojciech Zawadzki

Department of Animal Physiology

Wrocław University of Environmental and Life Sciences

ul. Norwida 31, 50-375 Wrocław, Poland
Phone: 4871320549

Fax: 48713205401

E-mail:wojwaza@gmail.com,wojciech.zawadzki@up.wroc.pl

http://www.vfu.cz/acta-vet/actavet.htm 
bean in the fodder has also a long-term effect on a decrease in the feed consumption (a long-term effect). The short-term effect is associated with changes within the oral cavity, whereas the long-lasting feeding results in a decrease in the concentration of ammonia and volatile fatty acids in the rumen contents. In the long-term effect, the fermentation process in the rumen is limited and a decrease in energy is provided for the animal (Silanikove et al. 2001). On account of the tannin content in the horse bean seeds, different horse bean varieties have been divided into low- and high-tannin ones. In the low-tannin varieties, the content of condensed tannins in the coated seeds does not exceed $0.04 \mathrm{mg} / \mathrm{g}$ dry mass of the seeds. The low-tannin varieties studied in this work include the following varieties (contents of tannin are given in parentheses in milligrams per gram of dry mass): Allbus (0.034 mg/g d. m.), Leo (0.026 mg/g d. m.), Olga (0.038 mg/g d. m.), Kasztelan (0.027 $\mathrm{mg} / \mathrm{g} \mathrm{d} . \mathrm{m}$.$) , Merlin (0.031 mg/g d. m.), and Mistral (0.021 mg/g d. m.). The high-tannin$ varieties were as follows: Akord (0.594 mg/g d. m.), Martin $(0.725 \mathrm{mg} / \mathrm{g} \mathrm{d} . \mathrm{m}$.$) , Neptun$ (0.750 mg/g d. m.), Optimal (0.755 mg/g d. m.), Redos (0.689 mg/g d. m.), and Sonet (0.716 mg/g d. m.).

The current knowledge of feeding of horse bean in ruminants is unsatisfactory and more data are needed.

\section{Materials and Methods}

The study was carried out on 15 sheep, (Polish Merino $\times$ Polish Heather Sheep hybrid at the age from 2 to 4 years and of the body mass of 30-45 kg) from which samples of the rumen fluid and contents were taken $2.5 \mathrm{~h}$ after the morning feeding. The sheep were fed hay and concentrate mixture J-161 DB411X manufactured by Provimi-Rolimpex S.A.

The material for analysis was collected through the cannule of the dorsal rumen sack, made in accordance with Dejneka and Zięba's method (1965). Incubation of the collected contents was conducted in the vessels in accordance with Barnett and Reid's method (1961) with Zawadzki's modification (1993). The incubation environment in the vessels included $50 \mathrm{ml}$ of the collected rumen fluid contents, $50 \mathrm{ml}$ of distilled water and $50 \mathrm{ml}$ of McDougall's artificial saliva of $\mathrm{pH}=6.9$ with the following composition (in $1 \mathrm{dm}^{3}$ of distilled water): $\mathrm{NaHCO}_{3}-9.60 \mathrm{~g}, \mathrm{KCl}-0.60 \mathrm{~g}, \mathrm{CaCl}_{2}-0.04 \mathrm{~g}, \mathrm{Na}_{2} \mathrm{HPO}_{4} \cdot 12 \mathrm{H}_{2} \mathrm{O}-9.15 \mathrm{~g}, \mathrm{NaCl}-0.45 \mathrm{~g}, \mathrm{MgSO}_{4} \cdot 7 \mathrm{H}_{2} \mathrm{O}-0.11$ $\mathrm{g}, \mathrm{ZnSO}_{4} \cdot \mathrm{H}_{2} \mathrm{O}-0.06 \mathrm{~g}, \mathrm{CaCl}_{2} \cdot 6 \mathrm{H}_{2} \mathrm{O}-0.01 \mathrm{~g}, \mathrm{NH}_{4} \mathrm{HCO}_{3}-0.5 \mathrm{~g}$. A control sample consisted of vessels including $50 \mathrm{ml}$ of the collected contents, $50 \mathrm{ml}$ of distilled water and $50 \mathrm{ml}$ of artificial saliva. A control sample was prepared individually for each experiment in order to eliminate differences in the fermentation activity of the rumen contents collected. The next vessels included $50 \mathrm{ml}$ of the filtered rumen contents, $50 \mathrm{ml}$ of distilled water and $50 \mathrm{ml}$ of artificial saliva as well as ground seeds of the low- and high-tannin horse bean at 3 different doses of 1,2 and $5 \mathrm{~g}$. Twenty fermentations were performed for each variant. The doses of 1,2 and $5 \mathrm{~g}$ were adopted from previous research. The total incubation volume of the samples in the vessels amounted to $150 \mathrm{ml}$ (with the total vessel volume of $250 \mathrm{ml}$ ). The vessel was made leak-proof by polished plugs and valves, covered with sealing silicon lubricant. Nitrogen was added to vessels under pressure to obtain anaerobic conditions. The gas was passed through the vessel contents for 10-15 min. Then, all the valves were closed. The maintaining of anaerobic conditions was checked with a DO-5508 device (manufactured by Lutron). The vessels prepared in this way were then placed in the seats of a shaker with a water bath of $39-42{ }^{\circ} \mathrm{C}$ and amplitude of 4 cycles per min. During incubation, samples of the contents were collected at the $4^{\text {th }}$ and $6^{\text {th }}$ hour of incubation in order to determine the content of ammonia, lactic acid, methane, $\mathrm{CO}_{2}$ as well as the $\mathrm{pH}$ of the fermented rumen contents. The ammonia level was determined using the Conway method, and the lactic acid and $\mathrm{CO}_{2}$ concentration was determined using the titration method. Methane concentration was measured using a methanometer of Barbara- 3 type. The $\mathrm{pH}$ of the collected samples of the incubated rumen contents was measured with a pH-meter (pX-processor PM-600). The research results were elaborated statistically by Student's $t$-test and the ANOVA variation analysis.

The experiment was conducted in accordance with protocol approved by the II Local Ethics Commission located at the Wroclaw Uviwersity of Enviromental and Life Sciences Poland.

\section{Results}

\section{Changes of ammonia concentration}

The addition of the low-tannin horse bean to the rumen contents fermented in in vitro conditions resulted in significant intensification of the fermentation processes in the rumen contents, especially the protein decomposition processes. A significant increase in ammonia concentration was noticed compared to the values obtained in the control sample. Bacterial fermentation of the horse bean seeds occurs very quickly, and ammonia concentration in 
Table 1. Values of the selected fermentation indicators of the sheep rumen contents with the addition of the low-tanin horse bean

\begin{tabular}{|l|c|c|c|c|c|c|}
\hline $\begin{array}{l}\text { Addition } \\
\text { weight }\end{array}$ & $\begin{array}{c}\text { Time of } \\
\text { sample } \\
\text { collection }\end{array}$ & $\begin{array}{c}\text { Ammonia } \\
(\mathrm{mmol} / \mathrm{l})\end{array}$ & $\begin{array}{c}\text { Lactic acid } \\
(\mathrm{mmol} / \mathrm{l})\end{array}$ & $\mathrm{pH}$ & $\begin{array}{c}\mathrm{CO}_{2} \\
(\mathrm{~mol} / \mathrm{l})\end{array}$ & $\begin{array}{c}\text { Methane } \\
(\% \mathrm{vol} .)\end{array}$ \\
\hline $1 \mathrm{~g}$ & $4 \mathrm{~h}$ & $4.49 \pm 0.61^{* *}$ & $2.33 \pm 0.46^{*}$ & $7.82 \pm 0.05$ & $0.00018 \pm 7.07 \bullet 10^{6 *}$ & $1.975 \pm 0.25$ \\
\hline & $6 \mathrm{~h}$ & $5.59 \pm 0.45^{* *}$ & $3.33 \pm 0.18$ & $8 \pm 0.081$ & & $2.025 \pm 0.28$ \\
\hline $2 \mathrm{~g}$ & $4 \mathrm{~h}$ & $5.98 \pm 1.45^{* *}$ & $3.66 \pm 0.38^{* *}$ & $7.87 \pm 0.095$ & $0.000217 \pm 2.21 \bullet 10^{5 * *}$ & $2.2 \pm 0.01$ \\
\hline & $6 \mathrm{~h}$ & $7.32 \pm 1.22^{* * *}$ & $4.21 \pm 0.24^{* *}$ & $7.87 \pm 0.095$ & & $2.05 \pm 0.17$ \\
\hline $5 \mathrm{~g}$ & $4 \mathrm{~h}$ & $8.99 \pm 0.45^{* * *}$ & $3.99 \pm 0.24^{* *}$ & $7.77 \pm 0.17$ & $0.00035 \pm 8.16 \bullet 10^{6 * *}$ & $2.075 \pm 0.05$ \\
\hline & $6 \mathrm{~h}$ & $15.71 \pm 0.86^{* * *}$ & $8.21 \pm 0.53^{* * *}$ & $7.72 \pm 0.15$ & & $2.1 \pm .015$ \\
\hline \multirow{2}{*}{ Control sample } & $4 \mathrm{~h}$ & $2.26 \pm 0.21$ & $1.77 \pm 0.09$ & $8.47 \pm 0.05$ & $0.00013 \pm 2.88 \bullet 10^{5}$ & $1.85 \pm 0.5$ \\
\cline { 2 - 7 } & $6 \mathrm{~h}$ & $2.4 \pm 0.43$ & $2.99 \pm 0.27$ & $8.42 \pm 0.095$ & & $1.7 \pm .01$ \\
\hline
\end{tabular}

* significant increase in the value compared to the control sample $p<0.05$

** significant increase in the value compared to the control sample $p<0.01$

${ }^{* * *}$ significant increase in the value compared to the control sample $p<0.005$

the rumen contents fermented with the addition of $1 \mathrm{~g}$ of the low-tannin horse bean was higher by $98.7 \%(p<0.01)$ on average at the $4^{\text {th }}$ hour; with the addition of $2 \mathrm{~g}$ it was higher by $164.93 \%(p<0.01)$; and with the addition of $5 \mathrm{~g}$ it was higher by $595.32 \%(p<0.005)$ compared to the values obtained in the control sample (Table 1). At the $6^{\text {th }}$ hour of the fermentation, ammonia concentration increased by $132.19 \%(p<0.01)$ in samples with the addition of $1 \mathrm{~g}$ of the low-tannin horse bean; with the addition of $2 \mathrm{~g}$ it was higher by $204.14 \%(p<0.005)$; and with the addition of $5 \mathrm{~g}$ it was higher by $552.92 \%(p<0.005)$ compared to ammonia concentration determined for the control sample at the $6^{\text {th }}$ hour of fermentation.

The addition of the high-tannin horse bean results in an increase of ammonia concentration by $255.07 \%(p<0.01)$ with the addition of $1 \mathrm{~g}$ of the horse bean at the $4^{\text {th }}$ hour of incubation; by $392.75 \%(p<0.01)$ with the addition of $2 \mathrm{~g}$; and by $386.08 \%$ $(p<0.005)$ with the addition of $5 \mathrm{~g}$ of the horse bean. At the $6^{\text {th }}$ hour of fermentation, ammonia concentration increased by $131.35 \%(p<0.05)$ with the addition of $1 \mathrm{~g}$ of the horse bean; by $278.3(p<0.005)$ with the addition of $2 \mathrm{~g}$; and by $307.96 \%(p<0.005)$ with the addition of $5 \mathrm{~g}$ (Table 2).

Table 2. Values of the selected fermentation indicators of the sheep rumen contents with the addition of the high-tanin horse bean

\begin{tabular}{|l|c|c|c|c|c|c|}
\hline $\begin{array}{l}\text { Addition } \\
\text { weight }\end{array}$ & $\begin{array}{c}\text { Time of } \\
\text { sample } \\
\text { collection }\end{array}$ & $\begin{array}{c}\text { Ammonia } \\
(\mathrm{mmol} / \mathrm{l})\end{array}$ & $\begin{array}{c}\text { Lactic acid } \\
(\mathrm{mmol} / \mathrm{l})\end{array}$ & $\mathrm{pH}$ & $\begin{array}{c}\mathrm{CO}_{2} \\
(\mathrm{~mol} / \mathrm{l})\end{array}$ & $\begin{array}{c}\text { Methane } \\
(\% \text { vol. })\end{array}$ \\
\hline $1 \mathrm{~g}$ & $4 \mathrm{~h}$ & $7.19 \pm 0.94^{* *}$ & $0.033 \pm 0.0023^{* *}$ & $8 \pm 0.05$ & $0.00024 \pm 4.54 \cdot 10^{5 *}$ & $2.17 \pm 0.05$ \\
\hline & $6 \mathrm{~h}$ & $8.01 \pm 1.08^{*}$ & $0.038 \pm 0.0030^{*}$ & $8 \pm 0.05$ & & $2 \pm 0.23$ \\
\hline $2 \mathrm{~g}$ & $4 \mathrm{~h}$ & $9.98 \pm 0.63^{*}$ & $0.039 \pm 0.053^{* *}$ & $7.97 \pm 0.05$ & $0.00028 \pm 2.98 \bullet 10^{5 * *}$ & $1.85 \pm 0.1$ \\
\hline & $6 \mathrm{~h}$ & $13.10 \pm 1.41^{* * *}$ & $0.063 \pm 0.015^{* *}$ & $7.87 \pm 0.15$ & & $1.9 \pm 0.2$ \\
\hline $5 \mathrm{~g}$ & $4 \mathrm{~h}$ & $9.84 \pm 0.47^{* * *}$ & $0.05 \pm 0.0067^{* *}$ & $7.8 \pm 0.14$ & $0.00037 \pm 3.20 \bullet 10^{5 * *}$ & $2.1 \pm 0.081$ \\
\hline & $6 \mathrm{~h}$ & $24.07 \pm 1.76^{* * *}$ & $0.068 \pm 0.010^{* * *}$ & $7.7 \pm 0.01$ & & $2.025 \pm 0.15$ \\
\hline \multirow{2}{*}{ Control sample } & $4 \mathrm{~h}$ & $3.45 \pm 0.17$ & $0.018 \pm 0.00061$ & $8.52 \pm 0.05$ & $0.00014 \pm 0.5 \cdot 10^{5}$ & $1.9 \pm 0.05$ \\
\cline { 2 - 7 } & $6 \mathrm{~h}$ & $5.9 \pm 0.18$ & $0.027 \pm 0.0025$ & $8.5 \pm 0.01$ & & $1.25 \pm 0.63$ \\
\hline
\end{tabular}

* significant increase in the value compared to the control sample $p<0.05$

** significant increase in the value compared to the control sample $p<0.01$

${ }^{* * *}$ significant increase in the value compared to the control sample $p<0.005$ 
Comparing ammonia concentration in the samples that included the low-tannin horse bean and the samples with the addition of the high-tannin horse bean, a certain relation can be observed. The addition of the high-tannin horse bean caused a higher increase of ammonia concentration in the fermented contents when added at low doses of 1 and $2 \mathrm{~g}$. At the $4^{\text {th }}$ hour of fermentation, ammonia concentration in samples with ground high-tannin horse bean seeds was higher by $58.6 \%(p<0.01)$ when $1 \mathrm{~g}$ was added and by $66.66 \%$ $(p<0.01)$ when $2 \mathrm{~g}$ of seeds were added compared to the values obtained in samples with the low-tannin horse bean. At the $6^{\text {th }}$ hour of fermentation, ammonia concentration was higher by $43.38 \%(p<0.05)$ in samples with the addition of $1 \mathrm{~g}$ of the high-tannin horse bean and by $78.98 \%(p<0.01)$ with the addition of $2 \mathrm{~g}$ of seeds compared to the values obtained in the samples with the low-tannin horse bean. When a higher dose of $5 \mathrm{~g}$ of the high-tannin horse bean was added, higher concentration of ammonia in samples with the high-tannin horse bean was no longer observed.

At the $4^{\text {th }}$ hour of fermentation, the ammonia concentration in the samples with the high-tannin horse bean was higher by $9.46 \%$ (not a significant change) compared to the values obtained in the samples with the low-tannin horse bean. However, at the $6^{\text {th }}$ hour of fermentation, the ammonia concentration in the case of the high-tannin horse bean was lower by $10.8 \%(p<0.05)$ than in the case of the low-tannin horse bean.

\section{Changes of the lactic acid concentration}

The addition of the low-tannin horse bean resulted in an increase of lactic acid concentration in the determined sample by o $31.25 \%(p<0.05)$ with the addition of $1 \mathrm{~g}$ of the horse bean at the $4^{\text {th }}$ hour of fermentation; by $106.25 \%(p<0.01)$ with the addition of $2 \mathrm{~g}$ of the horse bean; and by $125 \%(p<0.01)$ with the addition of $5 \mathrm{~g}$ of the seeds compared to the lactic acid concentration in the control sample (Table 1). At the $6^{\text {th }}$ hour of fermentation, lactic acid concentration increased by $11.11 \%$ with the addition of $1 \mathrm{~g}$ (not a significant increase), by $40.74 \%(p<0.01)$ with the addition of $2 \mathrm{~g}$, and by $174.07 \%$ $(p<0.005)$ with the addition of $5 \mathrm{~g}$ of the horse bean seeds compared to the lactic acid concentration in the control sample.

The addition of high-tannin horse bean seeds caused a much higher increase in lactic acid concentration than low-tannin horse bean seeds. At the $4^{\text {th }}$ hour of fermentation, the increase of lactic acid concentration after the addition of $1 \mathrm{~g}$ of high-tannin horse bean seeds to the examined sample amounted to $83.33 \%(p<0.01)$, whereas the addition of $2 \mathrm{~g}$ and $5 \mathrm{~g}$ resulted in an increase in concentration by $116.66 \%(p<0.01)$ and $177.77 \%$ $(p<0.01)$, respectively. At the $6^{\text {th }}$ hour of fermentation, increases of lactic acid concentration amounted to: $40.74 \%(p<0.05)$ with the addition of $1 \mathrm{~g}, 133.33 \%(p<0.01)$ with the addition of $2 \mathrm{~g}$, and $151.85 \%(p<0.005)$ with the addition of $5 \mathrm{~g}$ of the horse bean seeds (Table 2).

Comparison of lactic acid concentrations obtained in samples with the low- and hightannin horse bean, the addition of the high-tannin horse bean results in noticeably higher increases of lactic acid concentration when small doses of 1 and $2 \mathrm{~g}$ are added than the same addition of the low-tannin horse bean. The addition of the high-tannin horse bean at higher doses results in lower increases of lactic acid concentration compared to the lowtannin horse bean.

\section{Changes of $\mathrm{CO}_{2}$ concentration}

The addition of the low-tannin horse bean at the $4^{\text {th }}$ hour of fermentation causes an increase in $\mathrm{CO}_{2}$ concentration by $38.46 \%(p<0.05)$ when $1 \mathrm{~g}$ of the horse bean seeds is added; by $66.92 \%(\mathrm{p}<0.01)$ with the addition of $2 \mathrm{~g}$; and by $169 \%(p<0.01)$ with the addition of $5 \mathrm{~g}$ compared to the values obtained in the control samples.

The addition of the high-tannin horse bean at the $4^{\text {th }}$ hour of fermentation causes an increase in $\mathrm{CO}_{2}$ concentration by $98.26 \%(p<0.05)$ when $1 \mathrm{~g}$ of the horse bean seeds is 
added; by $100 \%(p<0.01)$ with the addition of $2 \mathrm{~g}$; and by $164.28 \%(p<0.01)$ with the addition of $5 \mathrm{~g}$ compared to the values obtained in control samples.

Comparing $\mathrm{CO}_{2}$ concentration obtained in samples with the low- and high-tannin horse bean, it can be observed that the addition of the high-tannin horse bean at small doses of 1 and $2 \mathrm{~g}$ caused a higher increase of $\mathrm{CO}_{2}$ concentration by $122.22 \%$ and $29.03 \%$, respectively, than the addition of the same amount of the low-tannin horse bean. The addition of the high-tannin horse bean at higher doses results in a lower increase of $\mathrm{CO}_{2}$ concentration (only by $5.71 \%$ ) compared to the low-tannin horse bean.

\section{Changes of the methane concentration}

The addition of the low-tannin horse bean at the $4^{\text {th }}$ hour of fermentation causes an increase in methane concentration by $6.75 \%$ when $1 \mathrm{~g}$ of the horse bean seeds is added; by $18.91 \%$ with the addition of $2 \mathrm{~g}$; and by $11.89 \%$ with the addition of $5 \mathrm{~g}$ compared to the values obtained in the control samples.

At the $6^{\text {th }}$ hour of fermentation, increases of methane concentration amounted to: $19.11 \%$ with the addition of $1 \mathrm{~g} ; 20.58 \%$ with the addition of $2 \mathrm{~g}$; and $23.52 \%$ with the addition of $5 \mathrm{~g}$ of the horse bean seeds compared to methane concentration in the control sample.

The addition of the high-tannin horse bean at the $4^{\text {th }}$ hour of fermentation caused an increase in methane concentration by $14.21 \%$ when $1 \mathrm{~g}$ of the horse bean seeds is added; a decrease by $2.63 \%$ with the addition of $2 \mathrm{~g}$; and an increase by $10.62 \%$ with the addition of $5 \mathrm{~g}$ compared to the values obtained in control samples. At the $6^{\text {th }}$ hour of fermentation, the increases of methane concentration amounted to: $60 \%$ with the addition of $1 \mathrm{~g} ; 52 \%$ with the addition of $2 \mathrm{~g}$; and $61.6 \%$ with the addition of $5 \mathrm{~g}$ of the horse bean seeds.

Comparing methane concentration obtained in samples with the low- and high-tannin horse bean, it can be observed that the addition of the high-tannin horse bean generally caused a decrease in methane concentration. Comparing methane concentration obtained in samples with the addition of the low- and high-tannin horse bean at a dose of only $1 \mathrm{~g}$ per sample at the $4^{\text {th }}$ hour of fermentation, an increase in methane concentration by $10.15 \%$ was obtained when the high-tannin horse bean was added. However, when the doses of 2 and $5 \mathrm{~g}$ were added, methane concentration decreased by $15.9 \%$ and $2.38 \%$, respectively. At the $6^{\text {th }}$ hour of fermentation, methane concentrations lower by $2.43 \%$ (at the dose of $1 \mathrm{~g}$ ), $7.31 \%$ (at the dose of $2 \mathrm{~g}$ ) and by 3.8 (at the dose of $5 \mathrm{~g}$ ) were observed in samples with the high-tannin horse bean than with the same addition of the low-tannin horse bean.

\section{Changes of $\mathrm{pH}$}

The addition of the low-tannin horse bean to the fermented contents caused a decrease of the $\mathrm{pH}$ of the fermented sample by $7.67 \%$ when $1 \mathrm{~g}$ of the horse bean seeds was added at the $4^{\text {th }}$ hour of the fermentation; by $7.08 \%$ with the addition of $2 \mathrm{~g}$; and by $8.26 \%$ with the addition of $5 \mathrm{~g}$ compared to the values obtained in control samples. At the $6^{\text {th }}$ hour of fermentation, a comparable decrease in the $\mathrm{pH}$ of the fermented contents was noted, by: $5.25 \%$ with the addition of $1 \mathrm{~g} ; 6.53 \%$ with the addition of $2 \mathrm{~g}$; and $8.31 \%$ with the addition of $5 \mathrm{~g}$ of the horse bean seeds.

The addition of the high-tannin horse bean at the $4^{\text {th }}$ hour of fermentation causes a decrease of the $\mathrm{pH}$ of the fermented contents by $6.1 \%$ with the addition of $1 \mathrm{~g}$ of the horse bean seeds; by $6.45 \%$ with the addition of $2 \mathrm{~g}$, and by $8.45 \%$ with the addition of $5 \mathrm{~g}$ compared to the values obtained in control samples. At the $6^{\text {th }}$ hour of fermentation, the registered decrease in the $\mathrm{pH}$ of the fermented contents was comparable with the decrease noted at the $4^{\text {th }}$ hour and amounted to: $5.88 \%$ with the addition of $1 \mathrm{~g} ; 7.41 \%$ with the addition of $2 \mathrm{~g}$; and $9.41 \%$ with the addition of $5 \mathrm{~g}$ of the horse bean seeds.

Comparing the changes of $\mathrm{pH}$ values of the fermented contents obtained in samples with the addition of the low- and high-tannin horse bean, it can be observed that the decrease of the $\mathrm{pH}$ of the fermented contents was comparable for both cases. 


\section{Discussion}

Horse bean seeds are a valuable fodder supplement in ruminant feeding for their high protein content. Protein contained in the horse bean seeds is very valuable and is subject to quick decomposition in the rumen contents, intensifying the rumen fermentation processes as confirmed by this work. The addition of only $1 \mathrm{~g}$ of the horse bean results in a significant increase in the concentration of ammonia, lactic acid, $\mathrm{CO}_{2}$, methane, and a decrease in the $\mathrm{pH}$ of the fermented contents compared to control samples. The ammonia concentration in the samples with the addition of the low-tannin horse bean grows by nearly $100 \%$ already at the dose of $1 \mathrm{~g}$. Higher doses cause proportionally higher increases in ammonia concentration. Changes of lactic acid concentration in samples with the addition of horse bean are equally high. Intensification of the fermentation process observed in samples with the addition of horse bean seeds also manifests itself as an increase in the fermentation gases, $\mathrm{CO}_{2}$ and methane. The increase in $\mathrm{CO}_{2}$ concentration is significant and is as high as the increase in the concentration of ammonia and lactic acid, reaching $100 \%$ with the addition of $1 \mathrm{~g}$ of the high-tannin lupin seeds. However, increases of methane concentration observed for the addition of the low-tannin horse bean are considerably lower, reaching a maximum of $23.52 \%$, but only at the $6^{\text {th }}$ hour of fermentation. At the same hour of fermentation, analogous changes of ammonia and lactic acid concentrations considerably exceeded $100 \%$. Only in the case of the high-tannin horse bean the increase of methane was slightly higher and amounted to approximately $60 \%$ at the $6^{\text {th }}$ hour of fermentation. The observed decrease in the $\mathrm{pH}$ of the fermented contents is caused by the increase of the concentration of volatile fatty acids, which is due to the process of rumen contents. Intensification of fermentation is caused by the addition of the horse bean seeds to the fermented samples, which gives the animal valuable extra energy and amino acids necessary for the correct functioning of the organism.

Considering the differences between the low-tannin and high-tannin horse bean, it can be observed that at low doses of 1 and $2 \mathrm{~g}$, the addition of the high-tannin horse bean causes greater intensification of the fermentation process in relation to the analogous addition of the low-tannin horse bean. This is manifested by higher increases of the concentration of ammonia, lactic acid, $\mathrm{CO}_{2}$ and methane. However, when a higher dose of $5 \mathrm{~g}$ per sample is added, an opposite tendency can be observed. At higher doses, the addition of the high-tannin horse bean causes lower increases of the concentration of selected indicators than analogous addition of low-tannin horse bean seeds. The hightannin horse bean in high doses limited the fermentation process resulting from the presence of the additional amount of protein, fat, and mineral compounds contained in the horse bean. Limitation of the fermentation process in the case of addition of the high-tannin horse bean at high doses is likely to result from a high content of tannins, which is proved by the results obtained by Silanikove et al. (1994; 1996; 1997). The authors pointed out that the anti-nutritional impact of tannins consisted of a reduction of bioavailability of the protein contained in the fodder as well as lowering of the activity of the enzymes secreted in the digestive tract; the pancreatic enzymes are particularly sensitive and their enzymatic activity is subject to considerable lowering in sheep and goats (Silanikove et al. 1994; Silanikove et al. 1996). Tannins considerably reduce digestibility of the plant cell walls through bonding with bacterial enzymes or forming indigestible complex compounds with carbohydrates of the cell walls (Barry et al. 1986; Reed 1986).

High tannin concentration significantly worsens protein digestibility as proved by numerous studies. In the in vitro research consisting of the incubation of bean (Barroga et. al. 1995) and horse bean (Carrido et al. 1991) seeds in a solution containing numerous enzymes, it was found that the presence of tannins decreased the decomposition of protein 
performed by enzymes. The research carried out by $\mathrm{McNabb}$ et al. (1998) examining the influence of tannins on solubility and degradation of the protein from Lotus pedunculatus by the carboxylaze enzymes from the rumen fluid, confirms the negative influence of tannins on protein decomposition. Research using leguminous plant seed fermentation with or without the addition of the substances that bind tannins also presented an important proof of the negative impact of tannins on the use of protein (Makkar et al. 1995; McSweeney et al. 1999; Palmer and Jones 2000; Jones et al. 2000). The addition of substances that bind tannins or proper heat treatment result in an increase of fermentation, which is manifested by a greater volume of gases created during rumen fermentation. The in vivo experiments carried out on ruminants also prove the influence of tannins on the extent of fodder digestibility. Putting a nylon or polyester sack filled with ground leguminous plant seeds in the rumen through the cannule of the dorsal rumen sack, which was made earlier, allowed to propose a thesis that tannins limit the use of nutrients in the fodder through limiting the decomposition processes. However, the addition of binding substances (PEGwater-soluble polyethylene glycol) prevents this process (Aharoni et al. 1998). This enables the breeder to obtain better economic results in breeding through a better use of fodder by the animals (Silanikove et al. 1997; Ben Salem et al. 2000). Research on goats fed oak leaves (that are rich in tannins) with the addition of soya seeds and PEG, the tannin-binding substances PEG, pointed out that the addition of PEG caused an increase in raw protein digestibility from 92 to $122 \mathrm{~g}$ per day. Consumption of the fodder also increased from 844 to $1,023 \mathrm{~g}$ per day (Silanikove et al. 1997). Tannins also have a direct impact on the fermentation activity of rumen microorganisms by lowering this activity (Silanikove et al. 1997).

This experimental model is widely used in the research into digestibility, providing much valuable information as the fodder decomposition processes occur in the natural environment of the rumen (Orskov and McDonald 1979; Khazaal 1993).

The addition of both the high-tannin and low-tannin horse bean intensifies rumen fermentation processes. The addition of the high-tannin horse bean at lower doses of 1 and $2 \mathrm{~g}$ causes higher increases of the rumen fermentation indicators under study. When higher doses of the high-tannin horse bean $(5 \mathrm{~g})$ are added, no differences in the examined fermentation indicators can be observed or, alternatively, a decrease in the indicators is noticed.

\section{References}

Aharoni Y, Gilboa N, Silanikove N 1998: Analysis of the suppressive effect of tannins on ruminal degradation by compartmental models. Anim Feed Sci Technol 71: 251-267

Barroga CF, Laurena AC, Mendoza EMT 1995: Effect of condensed tannins on the in vitro protein digestibility of mung bean (Vigna radiata L. Wilczek). J Agric Food Chem 33: 1157-1159

Barry TN, Manley RT, Duncan SJ, 1986: The role of condensed tannins in the nutritional value of Lotus pedunculatus for sheep. 4. Site of carbohydrate and protein digestion as influenced by dietary reactive tannin concentrations. Br J Nutr 55: 123-137

Barnett A J G, Reid RL 1961: Reactions in the rumen. Edward Arnold Ltd London.

Ben Salem H, Nefzaoui A, Ben Salem L, Tisserand JL 2000: Deactivation of condensed tannins in Acacia cyanophylla Lindl. Foliage by polyethylene glycol in feed blocks. Effect on feed intake, diet digestibility, nitrogen balance, microbial synthesis and growth by sheep. Livestock Prod Sci 64: 51-60

Carrido A, Gomez-Cabrera A, Guerrero JE, Van der Meer JM 1991: Effects of treatment with polyvinylpyrrolidone and polyethylene glycol on faba bean tannins. Anim Feed Sci Technol 35: 199-203

Dejneka J, Zięba D 1965: The method of creating cannula fistuli of rumen in sheep. Sci Lett Wrocław Agric Universit. 19: 177-180

Hart JH, Hillis WE 1972: Inhibition of wood-rotting fungi by ellagitannins in the heartwood of Quercus alba. Phytopathology 62: 620-626

Haslam E 1981: Vegetable Tannins. The Biochemistry of Plants, Vol. 7. Academic Press New York, pp. 527-554

Jasińska Z, Kotecki A 1993: Agricultural value of bracteate inflorescence horse bean main stems. Biul IHAR 186: $13-19$

Jasińska Z, Kotecki A 1998a: Characterization of main stems and strains bracteate inflorescence bean. Vol. I. Upgrowth, morphological features and crops. Sci Lett Agric University Wroclaw 73: 173-206 
Jasińska Z, Kotecki A 1998b: Characterization of main stems and strains bracteate inflorescence horse bean. Vol. II. Chemical composition and nutritional value of seeds. Sci Lett Agric University Wroclaw 73: 207-234 Jasińska Z, Kotecki A 2003: Detailed cultivation of plants. AR Wroclaw

Jones RJ, Palmer B 2000: In vitro digestion studies using ${ }^{14} \mathrm{C}$-labelled polyethylene glycol (PEG) 4000: comparison of six tanninferous shrub legumes and grass Panicum maximum. Anim Feed Sci Technol 85: 215-221

Khazaal K, Markantonatos X, Orskov ER 1993: Changes with maturity in fiber composition and levels of extractable polyphenols in Greek browse: effects on in vitro gas production and in sacco dry matter degradation. J Sci Food Agric 63: 237-244

Makkar HPS, Blummel M, Becker K 1995: Formation of complrxes between polyvinyl pyrrolidones or polyethylene glycols and tannins, and their implication in gas production and true digestibility in vitro techniques. Br J Nutr 73: 897-913

McNabb WC, Peters JS, Foo LY, Waghorn GC, Jakson FS 1998: Effect of condensed tannins prepared from several forages on the in vitro precipitation of ribulose-1,5-bisphosphate carboxylase (Rubisco) protein and its digestion by trypsin (EC 2.4.21.4) and chymotrypsin (EC 2.4.21.1). J Sci Food Agric 77: 201-212

McSweeney CS, Palmer B, Bunch R, Krause DO 1999: In vitro quality assessment of tannin-containing tropical shrub legumes: protein and fibre digestion. Anim Feed Sci Technol 82: 227-241

Orskov ER, McDonald I 1979: The estimation of protein degradability in the rumen from incubation measurements weighted according to rate of passage. J Agric Sci Camb 92: 499-503

Palmer B, Jones RJ 2000: The effect of PEG addition in vitro on dry matter and nitrogen digestibility of Calliandra calothyrsus and Leucanea leucocephala leaf. Anim Feed Sci Technol 85: 259-268

Pavlata L, Illek J, Pechová A, Matějiček M 2002: Selenium status of cattle in the Czech Republic. Acta Vet Brno 71: $3-8$

Provenza FD 1995: Postingestive feedback as an elementary determinant of food selaction and intake in ruminants. J Range Mgmt 48: 2-17

Reed JD 1986: Relationships among phenolics, insoluble proanthocyanidins and fiber in East African browse species. J Range Mgmt 39: 5-7

Scalbert A 1991: Antimicrobial Properties of Tannins. Phytochemistry Vol 30 No 12 Pergamon Press Oxford pp 3875-3883

Silanikove N, Nitsan Z, Perevolotsky A 1994: Effect of polyethylene glycol supplementation on intake and digestion of tannin-containing leaves (Ceratonia siliqua) by sheep. J Agric Food Chem 42: 2844-2847

Silanikove N, Gilboa A, Nir I, Perevolotsky A, Nitsan Z 1996: Effect of a daily supplementation of polyethylene glycol on intake and digestion of tannin-containing leaves (Quercus calliprinos, Pistacia lentiscus and Ceratonia siliqua) by goats. J Agric Food Chem 44: 199-205

Silanikove N, Gilboa N, Nitsan Z 1997: Interactions among tannins, supplementation, and polyethylene glycol in goats fed oak leaves. Anim Sci 64: 479-483

Silanikove N, Perevolotsky A, Provenza FD 2001: Use of tannin-binding chemicals to assay for tannins and their negative postingestive effects in ruminants. Anim Feed Sci Technol 91: 69-81

Jasińska Z, Kotecki A 1993: Agricultural value of bracteate inflorescence horse bean main stems. Biul IHAR 186: $13-19$

Jasińska Z, Kotecki A 1998: Characterization of main stems and strains bracteate inflorescence horse bean. Vol. I. Upgrowth, morphological features and crops. Sci Lett Agric University Wrocław 73: 173-206

Jasińska Z, Kotecki A 1998: Characterization of main stems and strains bracteate inflorescence horse bean. Vol. II. Chemical composition and nutritional value of seeds. Sci Lett Agric University Wrocław 73: 207-234

Jasińska Z, Kotecki A 2003: Detailed cultivation of plants. AR Wrocław

Zawadzki W 1993: The influence of some nonconventional feeds additives on the course of rumen fermentation in sheep. Sci Lett Wrocław Agric University 112: 5-69 